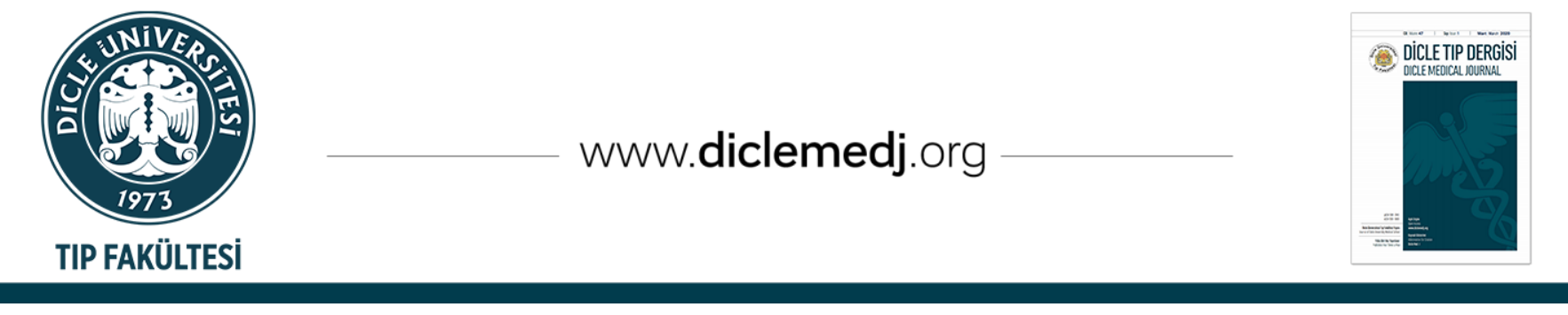

Özgün Araștırma / Original Article

\title{
Prolaktinoma Tanılı Hastalarda Prediyabet Sıklığı
}

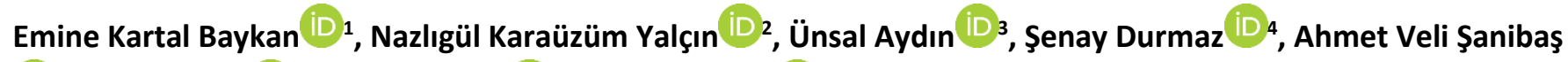 \\ (iD 2, ìdris Baydar iD 2, Aykut Turhan ${ }^{1}{ }^{2}$, Ayşe Çarlıoğlu iD 1 \\ 1 Erzurum Bölge Eğitim ve Araştırma Hastanesi $\quad$ Endokrinoloji ve Metabolizma Hastalıkları AB. Erzurum, Türkiye \\ 2 Erzurum Bölge Eğitim ve Araştırma Hastanesi Dahiliye AB. Erzurum, Türkiye
}

3 Özel Adana Hastanesi, Endokrinoloji ve Metabolizma Hastalıkları, Adana, Türkiye

4 Kırıkkale Üniversitesi Tıp Fakültesi, Endokrinoloji ve Metabolizma Hastalıkları ABD, Kırıkkale, Türkiye

Geliş: 11.07.2019; Revizyon: 27.05.2020; Kabul Tarihi: 03.06.2020

Öz

Amaç: Prolaktinin (PRL) çeşitli hayvan türlerinde glikoz intoleransı, hiperinsülinemi ve insülin direncini indüklediği daha önce yapılan çalışmalarda gösterilmiştir. Biz bu çalışmada prolaktinoma tanılı hastalarda metabolik etkilere yönelik daha fazla bilgi edinmeyi ve prediyabet sıklığını göstermeyi amaçladık.

Yöntemler: Çalışmamıza kliniğimizde takip ettiğimiz bilinen kronik hastalığı olmayan 30 prolaktinoma tanılı hasta ve kontrol grubu olarak benzer yaş, cinsiyet ve vücut kitle indeksi (VKi)'ne sahip 66 sağlıklı insan dahil edildi. Antropometrik parametreler (boy, kilo, VKI) ve serum hbA1c, açlık kan plazma glukozu(APG), PRL değerleri ölçüldü.

Bulgular: Prolaktinomalı hastalarda prediyabet anlamlı bir şekilde yüksek bulundu. Prolaktinoma ile APG arasında pozitif koreleasyon saptandı. Prolakinoma ile VKİ arasında pozitif koreleasyon saptandı.

Sonuç: Prolaktinomalı hastalarda prediyabet sıklığında artış saptandı. Prolaktinoma ile APG yüksekliği ve VKI'ndeki artış anlamlı bir şekilde ilişkiliydi.

Anahtar kelimeler: Prolaktinoma, prediyabet, vücut kitle indeksi

DOI: 10.5798/dicletip.755773

Correspondence / Yazışma Adresi: Nazlıgül Karaüzüm Yalçın, Erzurum Bölge Eğitim ve Araștırma Hastanesi Dahiliye AB. Erzurum, Türkiye e-mail: nazligulkarauzum@gmail.com 


\title{
Prediabetes Frequency in Patients With Prolaktinoma
}

\begin{abstract}
Objective: Objective: Studies have shown that prolactin (PRL) induces glucose intolerance, hyperinsulinemia and insulin resistance in various animal species. In this study, we aimed to get more information about the metabolic effects of prolactinoma in patients diagnosed with prolactinoma and to show the frequency of prediabetes in these patients.

Methods: The study included 30 patients with prolactinoma without any chronic disease in our clinic and 66 healthy people with similar age, gender and body mass index (BMI) as the control group. Anthropometric parameters (height, weight, BMI), serum HBA1c, fasting blood plasma glucose (FPG) and PRL values were measured.
\end{abstract}

Results: Prediabetes was significantly higher in patients with prolactinoma. There was a positive correlation between prolactinoma and FPG. and BMI. A positive correlation was found between prolactinoma and BMI.

Conclusion: An increased frequency of prediabetes was detected in patients with prolactinomas. Prolactinoma was significantly associated with increased FPG and increased BMI.

Keywords: Prolactinoma, prediabetes, body mass index.

\section{GíRiş}

Hiperprolaktinemi, hipotalamo-hipofizer yolakta en sı gözlenen endokrin hastalıktır. Toplumda prevalansı \%0,4-17 arasındadır. En sık ovülasyon bozukluğu görülen kadınlarda (\%9-17) saptanır ${ }^{1}$. Hastaların \%70'den fazlası kadındır². Gebelik, primer hipotiroidi ve PRL düzeyini etkileyen ilaç kullanımı en sık rastladığımız hiperprolaktinemi nedenleridir. $\mathrm{Bu}$ nedenleri ekarte ettiğimizde en önemli kronik hiperprolaktinemi sebebi prolaktinomadır. Prolaktinoma otopsi serilerinde fonksiyonel hipofiz adenomları içerisinde en fazla saptanandır ${ }^{3}$. Prolaktinomalar hormon sekrete eden hipofiz tümörleri arasında en sık rastlanılan formdur ${ }^{4,5}$. Tüm hipofiz tümörlerinin yaklaşık \%40'ını oluştururlar6. Prediyabet terimi, kan şekeri düzeylerinin diyabet tanısı konacak kadar yüksek olmadığı, ancak normal kabul edilen değerlerin de üzerinde olduğu durumlarda kullanılmaktadır. Açlık plazma glukozunun (APG) 100-125 mg/dL arasinda olması "bozulmuş açlık glukozu (BAG)" ve/veya oral glukoz tolerans testinde $75 \mathrm{~g}$ glukoz sonrası 2 . saat plazma glukozunun $140-199 \mathrm{mg} / \mathrm{dL}$ olması "bozulmuş glukoz toleransı (BGT)" ve/veya HbA1c değerlerinin \%5,7-6,4 olması prediyabet olarak kabul edilir ${ }^{7}$. Prediyabet tanısı alan çoğu insanda aynı zamanda insülin direnci de mevcuttur ${ }^{8}$. Prediyabet hem diyabet hem de kardiyovasküler hastalık riskini artırmaktadır. Hem BAG hem de BGT, obezite (özellikle viseral veya santral), hipertansiyon ve dislipidemi ile ilișkilidir ${ }^{9}$.

Prolaktinoma son zamanlarda bir çok çalışmada obezite ve onun insülin direnci ve metabolik sendrom gibi komplikasyonları ile ilişkilendirilmiştir ${ }^{10-12}$. PRL pankreas ve adernal bez üzerine doğrudan etkileri gösterilmiştir 13,14 . PRL gebelikte pankreas beta hücresi üzerinden glukoz dengesinin sağlanmasına olumlu etkide bulunur. Ancak prolaktinomaya sekonder hiperprolaktinemide PRL yüksekliği insülin direncini artırır ${ }^{14}$.

Biz bu çalışmada prolaktinoma tanılı hastalarda metabolik etkilere yönelik daha fazla bilgi edinmeyi ve prolaktinomada prediyabet sıklığını göstermeyi amaçladık.

\section{YÖNTEMLER}

$\mathrm{Bu}$ çalışma Endokrinoloji, İç hastalıkları polikliniğine başvuran prolaktinoma tanılı hastaların ve kontrol grubu olarak sağlıklı insanların çalıșmaya dahil edildiği vaka-kontrol araştırmasıdır. Katılımcılara yazılı bilgilendirilmiş onamlar imzalatılmıștır. Araştırma için Sağlık Bilimleri Üniversitesi Erzurum Bölge Eğitim ve Araștırma Hastanesi'nden 21.01.2019 tarihinde 
37732058-514.10 sayılı etik kurul kararı alınmıştır.

Çalışmamıza kliniğimizde takip ettiğimiz bilinen kronik hastalığı olmayan 30 prolaktinoma tanılı hasta (en az iki kez yüksek PRL seviyesi olan ve hipofiz adenomunun manyetik rezonans görüntüleme (MRI) kanıtı olan hastalar dahil edildi) (K/E: 27/3, yaş 39,4 $\pm 9,0$ ). Kontrol grubu olarak benzer yaş, cinsiyet ve vücut kitle indeksi (VKI)'ne sahip 66 sağlıklı insan (K/E:64/2, yaş $36,5 \pm 11,1$ ) dahil edildi.

Antropometrik parametreler (boy, kilo, VKİ) ve serum hbA1c, APG, PRL ölçüldü. Kan örnekleri 12 saat açlıktan sonra alındı. APG100-125 $\mathrm{mg} / \mathrm{dL}$ arasinda "BAG" olan ve/veya oral glukoz tolerans testinde $75 \mathrm{~g}$ glukoz sonrası 2. saat plazma glukozu 140-199 mg/dL "BGT" olan ve/veya HbA1c değerleri \%5,7-6,4 olan hastalar prediyabet olarak kabul edildi.

PRL ölçümü Abbott Architect i2000 (USA) otoanalizöründe kemilüminesan mikropartikül immünoassay yöntemi ile yapıldı. APG ölçümleri Abbott Architect c16000 (USA) otoanalizörü kullanarak yapıldı.

Serum PRL normal aralığı kadınlarda 1-27 $\mu \mathrm{g}$ / L, erkeklerde 1-20 $\mu \mathrm{g}$ / L olarak alındı.

\section{İstatiksel Analiz}

Veriler IBM SPSS 20 istatistik analiz programı kullanılarak analiz edildi. Veriler ortalama, standart sapma olarak gösterildi. ShapiroWilk testi sürekli değiş̧enlerin normal dağılımı için kullanıldı. İndependent Samples $\mathrm{t}$ testi iki bağımsız grup arasındaki karşılaştırmalarda normal dağılım sağlandığı durumda (VKİ ve yaş) kullanıldı. İki bağımsız grup arasındaki karşılaştırmada normal dağılım sağlanamadığında (PRL) Mann Whitney U testi kullanıldı. Pearson korelasyon testi iki devamlı değişkenin karşılaştırılmasında normal dağılım sağlanıyorsa kullanıldı. Spearman korelasyon testi ise normal dağılım sağlanmıyorsa kullanıldı. Bulgular \%95 güven aralığında ve istatistiksel anlamlılık düzeyi $\mathrm{p}<0,05$ olarak kabul edildi.

\section{BULGULAR}

Tablo I, araştırma grubunun parametre değerlerini ve özelliklerini göstermektedir. Çalışmamıza 30 prolaktinoma hastası ve kontrol grubu olarak benzer yaş, cinsiyet ve VKi' ye sahip 66 sağlıklı insan dahil edildi. Hastalar \%90 (n:27) kadın ve \%10 (n:3) erkekten oluşmaktaydı. Hastaların tanı anındaki ortalama yaşı 39,4 yıldı. Kontrol grubunun \%96’sı (n:64) kadın, \%4'ü (n:2) erkek ve tanı anındaki ortalama yaş 36,5 yıldı.

Tablo I: Çalışma grubunun parametre değerleri ve özellikleri

\begin{tabular}{|c|c|c|c|c|}
\hline & Grup & Ortalama & $\begin{array}{c}\text { Standart } \\
\text { Sapma }\end{array}$ & $P$ değeri \\
\hline \multirow[b]{2}{*}{ YAŞ } & Kontrol & 36,5 & 11,11 & \multirow[b]{2}{*}{0,210} \\
\hline & Prolaktinoma & 39,4 & 9,00 & \\
\hline \multirow[b]{2}{*}{ Vki } & Kontrol & 27,2 & 5,24 & \multirow[b]{2}{*}{0,76} \\
\hline & Prolaktinoma & 26,9 & 3,63 & \\
\hline \multirow[b]{2}{*}{ PROLAKTIN } & Kontrol & 13,4 & 5,65 & \multirow[b]{2}{*}{0,00} \\
\hline & Prolaktinoma & 166,4 & 82,34 & \\
\hline
\end{tabular}

Prolaktinoma tanılı hastalardan beşinde prediyabet saptandi. Kontrol grubunda ise prediyabet yoktu. Prolaktinoma tanılı hastalar ile sağlıklı kontrol grubu kiyaslandığında prediyabet sıklığı prolaktinomalı hastalarda artmış olarak bulundu (p 0.001) (Tablo II). PRL ile APG arasında pozitif koreleasyon saptand $\mathrm{p}$ 0,039). PRL ile VKİ arasında pozitif koreleasyon saptandi (p 0,00) (Tablo III).

Tablo II: Prolaktinoma ve Prediyabet

\begin{tabular}{|l|l|l|l|}
\hline & Kontrol & Prolaktinoma & Toplam \\
\hline Prediyabet Yok & 66 & 25 & 91 \\
\hline Prediyabet Var & 0 & 5 & 5 \\
\hline Toplam & 66 & 30 & 96 \\
\hline
\end{tabular}

P 0,001 
Tablo III: PRL ile Diğer Parametrelerin Korelasyon Değerlendirilmesi

\begin{tabular}{|l|c|c|}
\hline Değişkenler & $\begin{array}{l}\text { Korelasyon } \\
\text { katsayısı }\end{array}$ & P değeri (2-tailed) \\
\hline PREDiYABET & 0,259 & 0,111 \\
\hline YAŞ & 0,287 & 0,076 \\
\hline VKİ & $0,542^{* *}$ & 0,000 \\
\hline CíNSiYET & 0,188 & 0,251 \\
\hline APG & $0,332^{*}$ & 0,039 \\
\hline ** Korelasyon 0,01 düzeyinde anlamlıdır (2-tailed). \\
*Korelasyon 0,05 düzeyinde anlamlıdır (2-tailed).
\end{tabular}

\section{TARTIŞMA}

PRL çok fonksiyonlu bir hipofiz hormonudur. Prolaktinoma tanılı hastalarda, yüksek prolaktin değerlerinin metabolik değișikliklere sebep olduğu birçok çalışmada saptanmıştır. PRL hormonunun kronik yüksekliğinin vücut kitle indeksi, insülin direnci, tip 2 diyabetes mellitus ile ilişkisi araștırılmıştır. Ancak şimdiye kadar prolaktinoma ve prediyabet sıklığ konusunda herhangi bir araştırma yapılmadığ saptanmıştır.

Çalışmamızda prolaktinoma tanılı hastalar ile sağlıklı kontrol grubu kıyaslandığında prediyabet sıklığını prolaktinomalı hastalarda artmış olarak bulduk ve prolaktinoma tanılı hastaların PRL düzeyleri ile APG arasında pozitif korelasyon saptadık. Nazir A. Pala ve arkadaşlarının $^{15}$ yaptığı çalışmada da prolaktinoma tanılı hastaların, kontrol grubuna göre anlamlı derecede yüksek APG düzeylerine sahip olduğu gösterilmiștir. Hiperprolaktinemik hastalarda bazal ve uyarılmış insülin düzeyleri yüksek olarak bulunmuş. Hiperprolaktinemik hastalarda insülin direnci normal popülasyona göre yüksek saptanmıştır.

Asai-Sato ve arkadaşları yaptıkları bir çalışmada insan yağ dokusu kaynaklı adiposit spesifik protein olan adiponektinin, insülin duyarlılığı ile pozitif ilişkili bulmuşlar ve in vitro olarak PRL'nin adiponektin üretimini baskıladığını göstermişlerdir ${ }^{16}$.

Hiperprolaktinemide insülin duyarlılığında değişme olup olmadığını belirlemek için yapılan bir çalışmada, prolaktinomalı hastalarda adenom başarılı bir şekilde çıkarılmadan önce ve sonra glukoz, insülin, PRL, GH ve kortizol tetkikleri incelenmiș.

Hiperprolaktinemide insülin duyarlılığının selektif adenomektomi ile elde edilen normoprolaktinemiye göre daha düşük olduğu gösterilmiştir ${ }^{12}$.

Prolaktinomanın hiperlipidemi, düşük plazma lipoprotein lipaz aktivitesi ve insülin direnci ile karakterize metabolik anormalliklerle ilişkili olduğu saptanmıştır ${ }^{17,18}$.

Hiperprolaktinemi, aterosklerozun erken belirleyicileri olan bozulmuş endotel fonksiyonu ve azalan insülin duyarlılığı ile ilişkilidir. Bu değişiklikler, tedavi edilmemiş vakalarda ateroskleroz gelişimine yatkınlık gösterebilir ${ }^{19}$.

Çalışmamızda PRL düzeyleri ile VKİ arasında pozitif koreleasyon saptandık. Yapılan çalışmalarda hiperprolaktinemi vücut komposizyonunda değişiklik, yağ oranında artış ,artmış VKİ, insülin direnci ve metabolik sendrom arasında bir ilişki saptanmıştır ${ }^{20,21}$. Bunun sebebi olarak santral sinir sisteminde dopaminerjik tonusun bozulması ve lipogenezin uyarılması düşünülmektedir ${ }^{22}$. Hiperprolaktineminin gıda alımını ve yağ birikimini artırarak obeziteye sebep olabileceği gösterilmiştir ${ }^{10,23}$. İnsan yağ dokusu hücrelerinde PRL reseptörleri de gösterilmiştir ${ }^{22}$.

Makroprolaktinoma hastalarında ortalama VKI, inaktif adenomlu hastaların VKİ'den anlamlı derecede yüksektir. Genel popülasyonla karşılaştırıldığında, makroprolaktinomalı 
hastalarda VKİ anlamlı olarak daha yüksek saptanmıştır ${ }^{24,25}$.

Prolaktinomalı hastalarda tedavi öncesi ve tedavi sonrası yapılan çalışmalarda uzun etkili dopamin agonisti bromokriptin, dopaminerjik aktiviteyi artırarak, prolaktinomalı hastalarda PRL seviyelerini azaltmaya ek olarak vücut ağırlığını ve olası vücut kompozisyonunu etkileyebildiği saptanmıştır ${ }^{10}$. Tedavi sonucu normoprolaktinemi sağlanması ile VKİ tamamen normale gelmese de metabolik parametrelerde düzelme, kilo kaybı, insülin duyarlılı̆̆ında artma görülmüştür ${ }^{20}$. Tedavi sonrası normal PRL düzeyleri olan hastalarda düşük vücut yağ içeriğinin, düzenli dopamin agonist tedavisinin bir sonucu olarak yeterli dopamin reseptör tip 2 aktivasyonunun metabolik etkilerine bağlı olması muhtemeldir. $\mathrm{Bu}$ bulgu, prolaktinomalı kadınlarda dopamin agonistleri ile uygun tedavinin önemini güçlendirir, bu da PRL seviyelerini normalleștirmenin yanında, vücut yağ içeriğini ve bunun sonucu olarak metabolik sendrom ve komplikasyonlarının geliştirme riskini azaltır $^{21,26 .}$

Ayrica prolaktinomalı hastalarda tedavi sonrasında insülin duyarlılığında artış ve glukoz toleransında artma saptanmıştır ${ }^{27,28}$.

Bizim çalışmamızla prolaktinomalı hastalarda prediyabet sıklığı artmıș, vücut kitle indeksi ile pozitif korelasyon saptanmıştır. Bu olumsuz metabolik sonuçlar kardiyovasküler riski arttırmakta, mortaliteyi morbiditeyi olumsuz etkilemektedir. Prolaktinoma tanılı hastalar prediyabet ve metabolik sendrom açısından daha fazla risk altında olup yakından izlenmelidirler.

Etik Kurul Kararı: Araştırma için Sağlık Bilimleri Üniversitesi Erzurum Bölge Eğitim ve Araştırma Hastanesi'nden 21.01.2019 tarihinde 37732058-514.10 sayılı etik kurul kararı alınmıştır.
Çıkar Çatışması Beyanı: Yazarlar çıkar çatışması olmadığını bildirmişlerdir.

Finansal Destek: Bu çalışma her hangi bir fon tarafından desteklenmemiştir.

Declaration of Conflicting Interests: The authors declare that they have no conflict of interest.

Financial Disclosure: No financial support was received.

\section{KAYNAKLAR}

1. Biller $\mathrm{B}$, Luciano A, Crosignani $\mathrm{P}$, et al.: Guidelines for the diagnosis and treatment of hyperprolactinemia. The Journal of reproductive medicine 1999; 44 (12 Suppl): 1075-84.

2. Mindermann T, Wilson CB: Age-related and gender-related occurrence of pituitary adenomas. Clinical Endocrinology 1994; 41: 359-64.

3. Nomikos P, Buchfelder M, Fahlbusch R: Current management of prolactinomas. Journal of neuro-oncology 2001; 54: 139-50.

4. Fernandez A, Karavitaki N, Wass JA: Prevalence of pituitary adenomas: a community-based, cross-sectional study in Banbury (Oxfordshire, UK). Clinical endocrinology 2010; 72: 377-82.

5. Daly AF, Rixhon M, Adam C, et al.: High prevalence of pituitary adenomas: a crosssectional study in the province of Liege, Belgium. The Journal of Clinical Endocrinology \& Metabolism 2006; 91: 4769-75.

6. Daly AF, Tichomirowa MA, Beckers A: The epidemiology and genetics of pituitary adenomas. Best practice \& research Clinical endocrinology \& metabolism 2009; 23: 543-54.

7. Association AD: Diagnosis and classification of diabetes mellitus. Diabetes care 2014; 37 (Supplement 1): S81-S90. 
8. Ferrannini E, Gastaldelli A, Iozzo P: Pathophysiology of prediabetes. Medical Clinics 2011; 95: 327-339.

9. Association AD: Executive summary: Standards of medical care in diabetes--2014. Diabetes care 2014; 37:S5.

10. Doknic $M$, Pekic $S$, Zarkovic $M$, et al: Dopaminergic tone and obesity: an insight from prolactinomas treated with bromocriptine. European journal of endocrinology 2002; 147 : 77-84.

11. Shibli-Rahhal A, Schlechte J: The effects of hyperprolactinemia on bone and fat. Pituitary 2009; 12: 96-104.

12. Serri O, Beauregard H, Rasio E, Hardy J: Decreased sensitivity to insulin in women with microprolactinomas. Fertility and sterility 1986; 45: 572-4.

13. Park S, Kim DS, Daily JW, Kim SH: Serum prolactin concentrations determine whether they improve or impair $\beta$-cell function and insulin sensitivity in diabetic rats. Diabetes/metabolism research and reviews 2011; 27: 564-74.

14. Glasow A, Breidert M, Haidan A, et al: Functional aspects of the effect of prolactin (PRL) on adrenal steroidogenesis and distribution of the PRL receptor in the human adrenal gland. The Journal of Clinical Endocrinology \& Metabolism 1996; 81: 310311.

15. Pala NA, Laway BA, Misgar RA, Dar RA: Metabolic abnormalities in patients with prolactinoma: response to treatment with cabergoline. Diabetology \& metabolic syndrome 2015; 7: 99.

16. Asai-Sato $M$, Okamoto $M$, Endo $M$, et al: Hypoadiponectinemia in lean lactating women: Prolactin inhibits adiponectin secretion from human adipocytes. Endocrine journal 2006; 53 : 555-62.
17. Tuzcu A, Bahceci M, Dursun M, Turgut C, Bahceci S: Insulin sensitivity and hyperprolactinemia. Journal of endocrinological investigation 2003; 26: 341-6.

18. Pelkonen R, Nıkkılä EA, Grahne B: Serum lipids, postheparin plasma lipase activities and glucose tolerance in patients with prolactinoma. Clinical endocrinology 1982; 16: 383-90.

19. Yavuz D, Deyneli O, Akpinar I, et al: Endothelial function, insulin sensitivity and inflammatory markers in hyperprolactinemic pre-menopausal women. European Journal of Endocrinology 2003; 149: 187-94.

20. Santos-Silva CM, Barbosa FR, Lima GA, et al: BMI and metabolic profile in patients with prolactinoma before and after treatment with dopamine agonists. Obesity 2011; 19: 800-5.

21. Naliato EC, Violante AH, Caldas D, et al: Body fat in nonobese women with prolactinoma treated with dopamine agonists. Clinical endocrinology 2007; 67: 845-52.

22. Ling C, Svensson L, Odén B, et al: Identification of functional prolactin (PRL) receptor gene expression: PRL inhibits lipoprotein lipase activity in human white adipose tissue. The Journal of Clinical Endocrinology \& Metabolism 2003; 88: 1804-8.

23. Moore BJ, Gerardo-Gettens T, Horwitz BA, Stern JS: Hyperprolactinemia stimulates food intake in the female rat. Brain research bulletin 1986; 17: 563-9.

24. Goede D, Hauser R: Increased prevalence of high Body Mass Index in patients presenting with pituitary tumours: severe obesity in patients with macroprolactinoma. Swiss medical weekly 2006; 136 (1516).

25. Creemers L, Zelissen P, Van't Verlaat J, Koppeschaar H: Prolactinoma and body weight: a retrospective study. European Journal of Endocrinology 1991; 125: 392-6. 
26. Greenman Y, Tordjman K, Stern N: Increased body weight associated with prolactin secreting pituitary adenomas: weight loss with normalization of prolactin levels. Clinical endocrinology 1998; 48: 547-53.
27. Berinder K, Nyström T, Höybye C, Hall K, Hulting A-L: Insulin sensitivity and lipid profile in prolactinoma patients before and after normalization of prolactin by dopamine agonist therapy. Pituitary 2011; 14: 199-207.

28. Landgraf $\mathrm{R}$, Landgraf-Leurs $\mathrm{M}$, Weissmann A, et al.: Prolactin: a diabetogenic hormone. Diabetologia 1977; 13: 99-104. 